\title{
COVID-19 Dental Students' Knowledge of Medical Technical Institute Dental Assistant Department (Erbil-Iraq) A Comparative Study
}

\section{Faraed Dawood Salman ${ }^{1 *}$ and Jabbar Hussein Kamel ${ }^{2}$}

${ }^{1}$ Professor, Dental Assistant Department, Medical Technical Institute, Erbil

Polytechnique University, Erbil, Iraq

${ }^{2}$ Professor at Conservative Department, TISHK University, Head of Conservative

Department, Erbil, Iraq

*Corresponding Author: Faraed Dawood Salman, Professor, Dental Assistant

Department, Medical Technical Institute, Erbil Polytechnique University, Erbil, Iraq.
Received: July 29, 2021

Published: October 19, 2021

(C) All rights are reserved by Faraed Dawood

Salman and Jabbar Hussein Kamel.

\begin{abstract}
Background: This study is aimed to assess and compare the dental knowledge of dental assistant students' department (both stages) in Medical Technical Institute-Erbil-Iraq concerning covid-19 pandemic.

Materials and Methods: In this cross-sectional study, a questionnaire with 20 questions regarding causes, routes of transmission of virus, and source of knowledge was conducted among dental students in Medical Technical Institute. A total (91) students, (51) first stage, (40) second stage were individually questioned to complete a pretested questionnaire concerning their knowledge about covid-19 in order to increase compliance of students with universal precautions and to eliminate their deficiencies, their understanding should be determined, their source of information was used to update their knowledge about the disease and students training on new infection prevention control measure.

Results: First stage showed higher response than $2^{\text {nd }}$ stage concerning routes of transmission (84.3, 55\%), Interaction with animals (yes; 62.7, 35\%), preventive measures (90.2, 82.5\%) and source of dental knowledge (social media and TV) (56.9, 30\%, 29.4, 2.5\%) with significant difference between them, but with non-significant difference for mask types $(72.5,65 \%)$, treatment vary according to severity $(70.6,57.5 \%)$, hand sanitizer $(56.9,55 \%)$ and if it's safe to work in dental clinic during covid-19 (33.3, 25\%) and if signs increase with increasing severity of disease (yes, 74.5, 70\%). While $2^{\text {nd }}$ stage showed higher response than $1^{\text {st }}$ stage concerning interaction with animals (no; 32.5, 17.6\%), how many hours the virus stays on solid surfaces $(32.5,27.5 \%)$, source of knowledge (Journals 2.5, 2\%) and those who don't follow the updates $(20,11.8 \%)$ with significant difference between them, but with non-significant difference for symptoms duration range (14 days) $(57.5,45.1 \%)$, people at risk $(65,47.1 \%)$ and natural food supplement $(70$, $52.9 \%)$.

First and second stages were equal in their answers concerning causes, symptoms, covid virus differs from cold and flu virus, use of alcoholic wipe tissue, vaccine effectiveness and dietary supplement.

Conclusion: The findings of this study had shown that the knowledge of the students of both stages were good, although there were contradictions in their answers, deficient areas were observed in the knowledge of both stages that require prevention infection control covid-19 updates, practical guidelines of CDC, ADA and WHO should be included in the curriculum of the first stage prevention subject to control the spread of this pandemic.
\end{abstract}

Keywords: Covid-19; Pandemic; Knowledge; CDC; ADA; WHO

Citation: Faraed Dawood Salman and Jabbar Hussein Kamel. “COVID-19 Dental Students' Knowledge of Medical Technical Institute Dental Assistant Department (Erbil-Iraq) A Comparative Study". Acta Scientific Medical Sciences 5.11 (2021): 86-100. 


\section{Introduction}

The novel coronavirus disease [covid-19] is a communicable viral disease caused by the SARS cov-2 virus, which was identified around the end of December 2019 in Wuhan, China [1].

On January $30^{\text {th }}, 2020$, the world health organization [WHO] declared COVID-19 a public Health Emergency of International Concern [PHEIC] and on march 11th, 2020 it was declared to be a pandemic [2]. As a respiratory infection, the transmission pathways include the spread of aerosols and droplets [coughing and sneezing], and contacting an infected area or person.

Infection can also be a symptomatic, thus implying that infected people can be silent carriers, which causes more spread of the disease [2-4].

Health care workers, including dentists, dental assistants are at high risk at acquiring and transmitting infection within their work environment due to close contact with patients and the instruments they use that spread droplets, aerosols of blood and saliva [5]. Since the occupational for viral infections risk had not changed from a decade ago, COVID-19 is an unprecedented risk for both dental staff and patients [6,7].

Coping with the current situation is a challenge not only for dentists but also for dental students [8]. Amid this chaotic scenario, pandemics are also a huge challenge to health care professionals who are at high risk of being contaminated due to frequent exposure to contaminated patients $[9,10]$.

Dental students also might be facing several challenges to cope with the current pandemic [11-17].

Kurdistan Universities committed to the lock down, as did the dental faculties, immediately after the state of emergency declaration due to COVID-19 outbreak on March 5, 2020, in the middle of second semester. Theoretical education, including clinical cases discussion, switches to an online format, and clinical training in outpatient dental clinics stopped completely [18].

It is inevitable that dentistry faculty students with insufficient clinical experience will be more exposed to infectious diseases [19]. In previous diseases, occupational exposure to infective diseases in dental faculties has been reported as 66 - 80\% [19,20]. Many institutions have issued protocols to avoid further spread of covid-19 [21,22]. Many experts in the field of dental education have discussed the future of dental education from an institutional perspective $[13,15-17]$ which are essential reports on this serious issue.

\section{Aims of the Study}

The survey was conducted in mid-January 2021 to evaluate;

- Students' knowledge about COVID-19 virus symptomology, diagnosis and transmission pathway. In this study, students in the dental school were questioned in order to evaluate their knowledge level about COVID-19 in order to increase the compliance of dental students with universal precautions and eliminate their deficiencies, students' understanding should be determined.

- Source of students' information use to update their knowledge about the disease.

- Students training on new infection preventive control measures.

The challenging situation has offered an opportunity to re-evaluate dental knowledge and understanding of infection control measures related to dentistry and formulate new strategies in the post covid era [23].

\section{Materials and Methods}

Study design, participants, sample size determination

This study employed across-sectional survey design conducted via a questionnaire distributed to all dental students (first and second stages). First stage students no. 51 and second stage students no. 40 , total no. was 91 .

\section{Inclusion criteria}

All consenting participants of first and second stages' students studied at Dental Assistant Department/Medical Technical Institute in Erbil. It was explained at the beginning of the questionnaire that the purpose of data collection was for scientific research about COVID-19.

- Age: 18-22 years old.

- All gender: $($ female $=69$, male $=22)$ total 91 .

\section{Exclusion criteria: Incomplete questionnaire}

The construct of the survey was based on the latest literature resources about the new SARS-COV-2 and COVID-19 including nine parts;

- The first part: The questionnaire included demographic formation of the participants that is their age group and gender. 
- The $2^{\text {nd }}$ part: Assessed causes of COVID-19, routes of transmission, and interaction with animals.

- The $3^{\text {rd }}$ part: Assessed symptoms duration range, if symptoms number increase with increasing severity, if COVID-19 virus can be differentiated from common cold and flu.

- The $4^{\text {th }}$ part: Assessed people risk group (diabetic, hypertensive, obese and cancer).

- The $5^{\text {th }}$ part: Assessed preventive measures, hand sanitizing, use of alcoholic wipe tissue, wearing masks with its various types.

- The $6^{\text {th }}$ part: Assessed students' knowledge concerning how many hours does the virus stay on solid surfaces and if it is safe to work in dental clinic.

- The $7^{\text {th }}$ part: Assessed vaccine and treatment of COVID-19 if it varies according to its severity.

- The $8^{\text {th }}$ part: Assessed if natural and dietary food supplement are effective in preventing COVID-19.

- The $9^{\text {th }}$ part: Assessed source of dental knowledge (social media, TV, Journal or if they don't follow the updates).

\section{Statistical analysis}

Data management and statistical analysis will be recorded on a specifically designed questionnaire, collected and entered in the computer, then analyzed using appropriate data system which is called statistical package for social science (SPSS) version 25 and the result will be compared between students with different variables with statistical significance level of $\mathrm{P}<0.05$, the result will be presented as frequencies, percentages in tables analyzed using chi- square test.

\section{Results}

Among 91 students enrolled in the current study, majority [69] of them were female and only 22 of them were male; 51 of the students were from first stage and 40 students from second stage, 43 females from first stage and nearly quarter [26] of them were from second stage, 8 and 14 students were male from first and second stages. The mean age of first stage students was 18.76 years and the mean age of second year students was 19.50 years (Figure 1,2).

Table 1 reveals that there was a non-significant statistical association between stages and causes of COVID-19, the vast majority (96.1\%) of first stage and (92.5\%) of second stage thought the cause of COVID-19 was a virus, p- value was (0.018). There was a significant statistical association between stages and route of

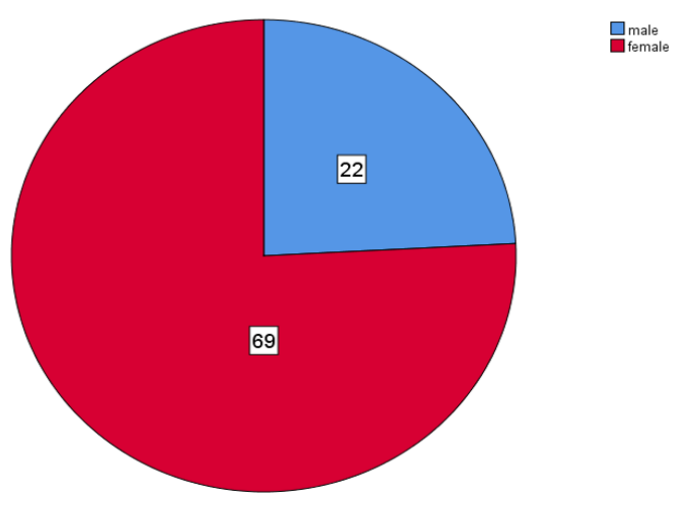

Figure 1: Gender distribution of the sample size.

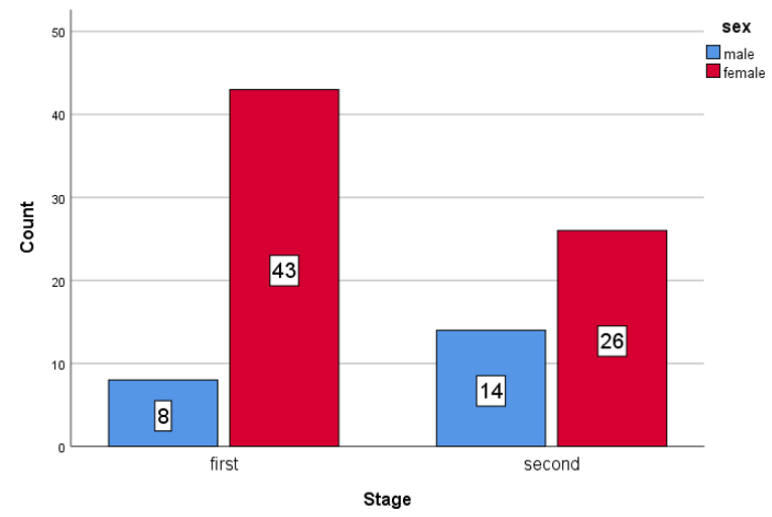

Figure 2: Gender distribution of first and second stages.

transmission, the majority (84.3\%) of first year students and more than half (55\%) of second stage thought that direct contact is one of the routes of transmission, while nearly one third (32.5\%) of second stage and only (7.8\%) of first stage said that sneezing is one of the routes of transmission. Chi square test was significant, and p-value was (0.007). There was a significant statistical association between stages and interaction with animals, most $(62.7 \%)$ of first stage and (35\%) of second stage students said that interaction with animals transmitted the disease, while (32.5\%) of second stage and (17.6\%) of first stage thought that interaction with animals 
didn't cause COVID-19. Chi square test was significant (p-value was $0.017)$.

\begin{tabular}{|c|c|c|c|c|}
\hline \multirow{2}{*}{ Variable } & \multirow{2}{*}{ Categories } & \multicolumn{2}{|c|}{ Stage } & \multirow{2}{*}{ P-value } \\
\hline & & First & Second & \\
\hline \multirow{8}{*}{$\begin{array}{l}\text { Causes of } \\
\text { COVID-19 }\end{array}$} & \multirow{2}{*}{ Bacteria } & 0 & 3 & \multirow{8}{*}{0.081} \\
\hline & & $0 \%$ & $7.5 \%$ & \\
\hline & \multirow{2}{*}{ Viruses } & 49 & 37 & \\
\hline & & $96.1 \%$ & $92.5 \%$ & \\
\hline & \multirow{2}{*}{ parasites } & 1 & 0 & \\
\hline & & $2 \%$ & $0 \%$ & \\
\hline & \multirow{2}{*}{ don't know } & 1 & 0 & \\
\hline & & $2 \%$ & $0 \%$ & \\
\hline \multirow{10}{*}{$\begin{array}{l}\text { Routes of } \\
\text { transmission }\end{array}$} & \multirow{2}{*}{ Direct contact } & 43 & 22 & \multirow{10}{*}{0.007} \\
\hline & & $84.3 \%$ & $55 \%$ & \\
\hline & \multirow{2}{*}{ Sneezing } & 4 & 13 & \\
\hline & & $7.8 \%$ & $32.5 \%$ & \\
\hline & \multirow{2}{*}{$\begin{array}{l}\text { Contaminated } \\
\text { food or drink }\end{array}$} & 1 & 2 & \\
\hline & & $2 \%$ & $5 \%$ & \\
\hline & \multirow{2}{*}{ Fecal } & 1 & 2 & \\
\hline & & $2 \%$ & $5 \%$ & \\
\hline & \multirow{2}{*}{ Don't know } & 2 & 1 & \\
\hline & & $3.9 \%$ & $2.5 \%$ & \\
\hline \multirow{9}{*}{$\begin{array}{l}\text { Interaction } \\
\text { with animals }\end{array}$} & \multirow{2}{*}{ Yes } & 32 & 14 & \multirow{9}{*}{0.017} \\
\hline & & $62.7 \%$ & $35 \%$ & \\
\hline & \multirow{2}{*}{ No } & 9 & 13 & \\
\hline & & $17.6 \%$ & $32.5 \%$ & \\
\hline & $\begin{array}{c}\text { Depends on type } \\
\text { of animal }\end{array}$ & 4 & 10 & \\
\hline & & $7.8 \%$ & $25.0 \%$ & \\
\hline & Don't know & 6 & 3 & \\
\hline & & $11.8 \%$ & $7.5 \%$ & \\
\hline & & $13.7 \%$ & $7.5 \%$ & \\
\hline Total & & 51 & 40 & \\
\hline $100 \%$ & & $100 \%$ & & \\
\hline
\end{tabular}

Table 1: Association between stages and route of transmission.

Findings of table 2 show that there was a non-significant association between stages and symptoms appear within, most (64.7\%) of first year students and (65\%) of second stage believed that from 7-14 days appeared symptoms of the disease, and p-value was (0.499). There was a non-significant association between first- and second-year students and symptoms duration range, more than half $(57.5 \%)$ of second stages and $(45.1 \%)$ of first stage thought that 14 days symptoms of the diseases remained. And p-value was (0.447). There was a non-significant association between stages and patients/cases, $(17.6 \%)$ of first stage and $(17.5 \%)$ of second stage said that cases were asymptotic. And p-value was (0.929). There was a non-significant association between stages and do signs and symptoms number increase with increasing severity, most $(74.5 \%)$ of first stage and $(70 \%)$ of second stage believed that signs and symptoms number increase with increasing severity, while only $(9.8 \%)$ of first stage and $(7.5 \%)$ of second stage said that signs and symptoms number did not increase with increasing severity, and p-value was (0.135). There was a non-significant association between stages and can COVID-19 virus be differentiated from common cold and flu, nearly half $(52.9 \%)$ of first stage and $(52.5 \%)$ of second stage thought that COVID-19 virus was different from common cold and flu, while $(15.7 \%)$ of first year students and $(7.5 \%)$ of second stage were not able to make differentiation between COVID-19 and common cold and flu. P-value was (0.525). There was a non- significant association between how we can differentiate COVID-19 symptoms from other respiratory disease, $(13.7 \%)$ of first stage and $(17.5 \%)$ of second stage believed that COVID-19 symptoms were different from respiratory diseases because of presence of fever, and p-value was (0.263).

\begin{tabular}{|c|c|c|c|c|}
\hline \multirow{2}{*}{ Variable } & \multirow{2}{*}{ Categories } & \multicolumn{2}{|c|}{ Stage } & \multirow{2}{*}{ P-value } \\
\hline & & First & Second & \\
\hline \multirow{8}{*}{$\begin{array}{l}\text { Symptoms } \\
\text { appear within }\end{array}$} & \multirow{2}{*}{ 2-5 days } & 8 & 7 & \multirow{8}{*}{0.499} \\
\hline & & $15.7 \%$ & $17.5 \%$ & \\
\hline & \multirow{2}{*}{ 5-7 days } & 9 & 4 & \\
\hline & & $17.6 \%$ & $10 \%$ & \\
\hline & \multirow{2}{*}{ 7-14 days } & 33 & 26 & \\
\hline & & $64.7 \%$ & $65 \%$ & \\
\hline & \multirow{2}{*}{ A month } & 1 & 3 & \\
\hline & & $2 \%$ & $7.5 \%$ & \\
\hline \multirow{9}{*}{$\begin{array}{l}\text { Symptoms } \\
\text { duration range }\end{array}$} & \multirow{2}{*}{ Last for 5 days } & 4 & 1 & \multirow{9}{*}{0.447} \\
\hline & & $7.8 \%$ & $2.5 \%$ & \\
\hline & \multirow{2}{*}{14 days } & 23 & 23 & \\
\hline & & $45.1 \%$ & $57.5 \%$ & \\
\hline & \multirow{2}{*}{ A month } & 18 & 10 & \\
\hline & & $35.3 \%$ & $25 \%$ & \\
\hline & \multirow{3}{*}{ Don't know } & 6 & 6 & \\
\hline & & $11.8 \%$ & $15 \%$ & \\
\hline & & $17.6 \%$ & $17.5 \%$ & \\
\hline
\end{tabular}




\begin{tabular}{|c|c|c|c|c|}
\hline \multirow{8}{*}{$\begin{array}{l}\text { Do signs and } \\
\text { symptoms' } \\
\text { number } \\
\text { increase with } \\
\text { increasing } \\
\text { severity }\end{array}$} & \multirow{2}{*}{ Yes } & 38 & 28 & \\
\hline & & $74.5 \%$ & $70 \%$ & \multirow{7}{*}{0.135} \\
\hline & \multirow{2}{*}{ No } & 5 & 3 & \\
\hline & & $9.8 \%$ & $7.5 \%$ & \\
\hline & \multirow{2}{*}{ Not sure } & 3 & 8 & \\
\hline & & $5.9 \%$ & $20 \%$ & \\
\hline & \multirow{2}{*}{ Don't know } & 5 & 1 & \\
\hline & & $9.8 \%$ & $2.5 \%$ & \\
\hline \multirow{8}{*}{$\begin{array}{l}\text { Can COVID-19 } \\
\text { virus be } \\
\text { differentiated } \\
\text { from common } \\
\text { cold and flue }\end{array}$} & \multirow{2}{*}{ Yes } & 27 & 21 & \multirow{8}{*}{0.525} \\
\hline & & $52.9 \%$ & $52.5 \%$ & \\
\hline & \multirow{2}{*}{ No } & 8 & 3 & \\
\hline & & $15.7 \%$ & $7.5 \%$ & \\
\hline & \multirow{2}{*}{ Not sure } & 10 & 8 & \\
\hline & & $19.6 \%$ & $20 \%$ & \\
\hline & \multirow{2}{*}{ Don't know } & 6 & 8 & \\
\hline & & $11.8 \%$ & $20 \%$ & \\
\hline
\end{tabular}

Table 2: Association between stages and symptoms of COVID-19.

Table 3 reveals that there was a non-significant association between stages and people at risk, (11.8\%) of first stage and only $(2.5 \%)$ of second year students thought that people with diabetes were more likely to have COVID-19, and (7.8\%) of first stage and $(10 \%)$ second stage said that people with hypertension were at risk in COVID-19 disease, and (47.1\%) of first stage and most $(65 \%)$ of second stage said that diabetes, hypertension, obesity and cancer were risk factors on people who had COVID-19 disease, while (19.6\%) of first students and (7.5\%) of second stage said that did not know what's risk factor on people with the disease. And p-value was (0.276).

\begin{tabular}{|c|c|c|c|c|}
\hline \multirow{2}{*}{ Variable } & \multirow{2}{*}{ Categories } & \multicolumn{2}{|c|}{ Stage } & \multirow{2}{*}{ P-value } \\
\hline & & First & Second & \\
\hline \multirow{12}{*}{$\begin{array}{l}\text { People at } \\
\text { risk }\end{array}$} & \multirow{2}{*}{ Diabetic } & 6 & 1 & \multirow{12}{*}{0.276} \\
\hline & & $11.8 \%$ & $2.5 \%$ & \\
\hline & \multirow{2}{*}{ hypertensive } & 4 & 4 & \\
\hline & & $7.8 \%$ & $10 \%$ & \\
\hline & \multirow{2}{*}{ Obese } & 4 & 3 & \\
\hline & & $7.8 \%$ & $7.5 \%$ & \\
\hline & \multirow{2}{*}{ Cancer } & 3 & 3 & \\
\hline & & $5.9 \%$ & $7.5 \%$ & \\
\hline & \multirow{2}{*}{ All the above } & 24 & 26 & \\
\hline & & $47.1 \%$ & $65 \%$ & \\
\hline & \multirow{2}{*}{ don't know } & 10 & 3 & \\
\hline & & $19.6 \%$ & $7.5 \%$ & \\
\hline
\end{tabular}

Table 3: Association between stages and risk factor.
Results of table 4 reveal that there was a non-significant statistical association between stages and sunlighteffective, (40\%) of second stage and (29.4\%) of first stage believed that sunlight was effective to prevent the disease, while nearly half (47.1\%) of first stage and more than quarter $(27.5 \%)$ of second stage thought that there was no prevention from sunlight, and p-value was (0.075). There was a significant statistical association between stages and release of oxygen (02) from plants, more than half $(52.5 \%)$ of second stage and (29.4\%) of first stage said that release of oxygen (O2) from plants prevented COVID-19 virus, while (45.1\%) of first year students and only (7.5\%) of second stage believed that release of oxygen (02) from plants did not prevent the disease. Chi square test was significant, and p-value was (0.001). There was a non-significant association between stages and preventive measures, majority $(90.2 \%)$ of first stage and $(82.5 \%)$ of second stage thought that preventive measures were beneficial, and p-value was (0.456). There was a non-significant association between stages and hand sanitizer, most (56.9\%) of first year students and (55\%) of second stage believed that hand sanitizer was effective, and one third (33.3\%) of first stage and quarter (25\%) of second stage though that it depends on the type of sanitizer, while only (2\%) of first stage and $(7.5 \%)$ of second stage said that hand sanitizer was unnecessary to prevent COVID-19 virus. And p-value was (0.457). There was a non-significant association between stages and use of alcoholic wipe tissues, (45.1\%) of first year students and (47.5\%) of second stage said that alcoholic wipe tissues prevented the disease, while $(21.6 \%)$ of first year students and $(12.5 \%)$ of second stage thought that use of alcoholic wipe tissues did not prevent the disease, $p$-value was (0.554). There was a non-significant association between stages and mask types, majority (72.5\%) of first year students and $(65 \%)$ of second stage thought that medical masks made prevention for the disease, while only (5\%) of second stage thought that non-medical masks prevented the disease. And p-value was (0.530). There was a non-significant association between stages and which option is highly significant among people, economy or preventing disease, (41.2\%) of first year students and more than one third (37.5\%) of second stage thought that economy state was more highly significant among people, while more than quarter $(27.5 \%)$ of first year students and (30\%) of second stage thought that preventing disease was highly significant among people, followed by (21.6\%) of first stage and (20\%) of second stage said that both economy and preventing disease were significant among people, $p$-value was $(0.960)$. There was a non-significant association between stages and does the type of mask affect preventive measures, more than half (54.9\%) of first stage and (52.5\%) of second stage thought that type of mask affected preventive measu- 
res, while only $(7.8 \%)$ of first year students and $(2.5 \%)$ said that type of mask had no effect on preventive measures, p-value was (0.581).

\begin{tabular}{|c|c|c|c|c|}
\hline \multirow{2}{*}{ Variable } & \multirow{2}{*}{ Categories } & \multicolumn{2}{|c|}{ Stage } & \multirow{2}{*}{$\begin{array}{c}\text { P- } \\
\text { value }\end{array}$} \\
\hline & & First & Second & \\
\hline \multirow{8}{*}{$\begin{array}{l}\text { Preventive } \\
\text { measures }\end{array}$} & \multirow{2}{*}{ Beneficial } & 46 & 33 & \multirow{8}{*}{0.456} \\
\hline & & $90.2 \%$ & $82.5 \%$ & \\
\hline & \multirow{2}{*}{ Not necessary } & 0 & 1 & \\
\hline & & $0 \%$ & $2.5 \%$ & \\
\hline & \multirow{2}{*}{$\begin{array}{c}\text { Doesn't prevent } \\
\text { disease }\end{array}$} & 2 & 1 & \\
\hline & & $3.9 \%$ & $2.5 \%$ & \\
\hline & \multirow{2}{*}{ Don't know } & 3 & 5 & \\
\hline & & $5.9 \%$ & $12.5 \%$ & \\
\hline \multirow{8}{*}{ Hand sanitizer } & \multirow{2}{*}{ Effective } & 29 & 22 & \multirow{8}{*}{0.467} \\
\hline & & $56.9 \%$ & $55 \%$ & \\
\hline & \multirow{2}{*}{ Not necessary } & 1 & 3 & \\
\hline & & $2 \%$ & $7.5 \%$ & \\
\hline & \multirow{2}{*}{$\begin{array}{l}\text { Depends on the } \\
\text { type of sanitizer }\end{array}$} & 17 & 10 & \\
\hline & & $33.3 \%$ & $25 \%$ & \\
\hline & \multirow{2}{*}{ Don't know } & 4 & 5 & \\
\hline & & $7.8 \%$ & $12.5 \%$ & \\
\hline \multirow{8}{*}{$\begin{array}{l}\text { Use of alcoholic } \\
\text { wipe tissues }\end{array}$} & \multirow{2}{*}{ Yes } & 23 & 19 & \multirow{8}{*}{0.554} \\
\hline & & $45.1 \%$ & $47.5 \%$ & \\
\hline & \multirow{2}{*}{ No } & 11 & 5 & \\
\hline & & $21.6 \%$ & $12.5 \%$ & \\
\hline & \multirow{2}{*}{ Not really } & 6 & 8 & \\
\hline & & $11.8 \%$ & $20 \%$ & \\
\hline & \multirow{2}{*}{ Don't know. } & 11 & 8 & \\
\hline & & $21.6 \%$ & $20 \%$ & \\
\hline \multirow{8}{*}{ Mask types } & \multirow{2}{*}{ Medical } & 37 & 26 & \multirow{8}{*}{0.530} \\
\hline & & $72.5 \%$ & $65 \%$ & \\
\hline & \multirow{2}{*}{ Non-medical } & 0 & 2 & \\
\hline & & $0 \%$ & $5 \%$ & \\
\hline & Both & 8 & 7 & \\
\hline & Dotn & $15.7 \%$ & $17.5 \%$ & \\
\hline & Don't know & 6 & 5 & \\
\hline & DOH L KHOW & $11.8 \%$ & $12.5 \%$ & \\
\hline & Yes & 28 & 21 & \\
\hline & Yes & $54.9 \%$ & $52.5 \%$ & \\
\hline Does the type & $\mathrm{No}$ & 4 & 1 & \\
\hline of mask affect & No & $7.8 \%$ & $2.5 \%$ & 0501 \\
\hline preventive & Not cure & 15 & 12 & 0.581 \\
\hline measures & ivot sure & $29.4 \%$ & $30 \%$ & \\
\hline & Don't wear mack & 4 & 6 & \\
\hline & Don l wear mask & $7.8 \%$ & $15 \%$ & \\
\hline
\end{tabular}

Data of table 5 show that there was a significant statistical association between dental stages and how many hours does the virus stay on solid, more than quarter $(27.5 \%)$ of first stage dental students and nearly one third (32.5\%) second stage thought that 8 hours the. virus stayed on solid, (13.7\%) of first stage and (20\%) of second stage dental students said that 2 days the virus stayed on solid. Chi square test was significant, and p-value was (0.003). There was a significant statistical association between dental stages and how many hours does the virus circulate in the air, (31.4\%) of first stage and more than one quarter $(27.5 \%)$ of second stage said that the virus 20 minutes remained in the air, while $(23.5 \%)$ of first stage and (15\%) of second stage thought that virus circulating in the air was not very specific. Chi square test was significant, and p-value was (0.026). There was a non-significant association between dental stages and is it safe to work in dental clinic during COVID-19 pandemic, one third (33.3\%) of first year dental students and quarter $(25 \%)$ of second stage said that working in dental clinic during COVID-19 is safe, while (47.1\%) of first dental stage and (45\%) of second stage said that working in dental clinic is not safe ( $\mathrm{p}: 0.483)$.

\begin{tabular}{|c|c|c|c|c|}
\hline \multirow{2}{*}{ Variable } & \multirow{2}{*}{ Categories } & \multicolumn{2}{|c|}{ Stage } & \multirow{2}{*}{ P-value } \\
\hline & & First & Second & \\
\hline \multirow{8}{*}{$\begin{array}{l}\text { How many } \\
\text { hours does the } \\
\text { virus stay on } \\
\text { solid objects/ } \\
\text { surface areas }\end{array}$} & \multirow{2}{*}{8 hours } & 14 & 13 & \multirow{8}{*}{0.003} \\
\hline & & $27.5 \%$ & $32.5 \%$ & \\
\hline & \multirow{2}{*}{2 days } & 7 & 8 & \\
\hline & & $13.7 \%$ & $20 \%$ & \\
\hline & \multirow{2}{*}{23 days } & 4 & 12 & \\
\hline & & $7.8 \%$ & $30 \%$ & \\
\hline & \multirow{2}{*}{ Not very specific } & 26 & 7 & \\
\hline & & $51 \%$ & $17.5 \%$ & \\
\hline \multirow{8}{*}{$\begin{array}{l}\text { Is it safe to } \\
\text { work in dental } \\
\text { clinic during } \\
\text { COVID-19 } \\
\text { pandemic }\end{array}$} & \multirow{2}{*}{ Yes } & 17 & 10 & \multirow[b]{8}{*}{0.483} \\
\hline & & $33.3 \%$ & $25 \%$ & \\
\hline & \multirow{2}{*}{ No } & 24 & 18 & \\
\hline & & $47.1 \%$ & $45 \%$ & \\
\hline & \multirow{2}{*}{ Not sure } & 7 & 6 & \\
\hline & & $13.7 \%$ & $15 \%$ & \\
\hline & \multirow{2}{*}{ Don't know } & 3 & 6 & \\
\hline & & $5.9 \%$ & $15 \%$ & \\
\hline
\end{tabular}

Table 5: Association between stages and dental student's knowledge.

Table 4: Association between stages and preventive measures. 
Findings of table 6 reveal that there was a non-significant association between stages and do treatment options of COVID-19 vary according to case severity, majority (70.6\%) of first stage and more than half (57.5\%) of second stage thought that treatment options of COVID-19 vary according to case severity, while only (2\%) of first stage and (12.5\%) of second stage thought that treatment options of COVID-19 don't vary according to case severity, and p-value was (0.273). There was a non-significant association between do you think that vaccine is effective in preventing the disease, $(45.1 \%)$ of first stage and (45\%) of second stage thought that vaccine was effective to prevent that disease, while (19.6\%) of first year students and $(22.5 \%)$ of second stage thought that vaccine was not effective in preventing the disease, and p-value was (0.935).

\begin{tabular}{|c|c|c|c|c|}
\hline \multirow{2}{*}{ Variable } & \multirow{2}{*}{ Categories } & \multicolumn{2}{|c|}{ Stage } & \multirow{2}{*}{ P-value } \\
\hline & & First & Second & \\
\hline \multirow{4}{*}{$\begin{array}{l}\text { Do treatment } \\
\text { options of } \\
\text { COVID-19 vary } \\
\text { according to } \\
\text { case severity }\end{array}$} & Yes & $\begin{array}{c}36 \\
70.6 \%\end{array}$ & $\begin{array}{c}23 \\
57.5 \%\end{array}$ & \multirow{4}{*}{0.273} \\
\hline & No & $\begin{array}{c}1 \\
2 \%\end{array}$ & $\begin{array}{c}5 \\
12.5 \%\end{array}$ & \\
\hline & Not sure & $\begin{array}{c}8 \\
15.7 \%\end{array}$ & $\begin{array}{c}7 \\
17.5 \%\end{array}$ & \\
\hline & Don't know & $\begin{array}{c}6 \\
11.8 \%\end{array}$ & $\begin{array}{c}5 \\
12.5 \%\end{array}$ & \\
\hline \multirow{4}{*}{$\begin{array}{l}\text { Do you think } \\
\text { that } \\
\text { vaccine is } \\
\text { effective } \\
\text { in preventing } \\
\text { the }\end{array}$} & Yes & $\begin{array}{c}23 \\
45.1 \%\end{array}$ & $\begin{array}{c}18 \\
45 \%\end{array}$ & \multirow{4}{*}{0.935} \\
\hline & No & $\begin{array}{c}10 \\
19.6 \%\end{array}$ & $\begin{array}{c}9 \\
22.5 \%\end{array}$ & \\
\hline & Not sure & $\begin{array}{c}14 \\
27.5 \%\end{array}$ & $\begin{array}{c}9 \\
22.5 \%\end{array}$ & \\
\hline & Don't know & $\begin{array}{c}4 \\
7.8 \%\end{array}$ & $\begin{array}{c}4 \\
10 \%\end{array}$ & \\
\hline
\end{tabular}

Table 6: Association between stages and treatment of COVID-19.

Finding of table 7 reveal that there was a non-significant association between stages and do you believe that natural food supplements are effective in preventing the disease, nearly half (52.9\%) of first year students and most (70\%) of second stage believed that natural food supplements are effective in preventing the disease, while only $(15.7 \%)$ of first year students and $(2.5 \%)$ of second stage believed that natural food supplements are not effective in preventing the disease, and p-value was (0.151). There was a nonsignificant association between stages, and do you believe that dietary supplements are effective in preventing the disease, most $(68.6 \%)$ of first stage and $(62.5 \%)$ of second stage believed that dietary supplements are effective in preventing the disease, while only (3.9\%) of first stage and (15\%) of second stage believed that dietary supplements are not effective in preventing the disease, and p-value was (0.323).

\begin{tabular}{|c|c|c|c|c|}
\hline \multirow{2}{*}{ Variable } & \multirow{2}{*}{ Categories } & \multicolumn{2}{|c|}{ Stage } & \multirow{2}{*}{ P-value } \\
\hline & & First & Second & \\
\hline \multirow{8}{*}{$\begin{array}{l}\text { Do you believe } \\
\text { that natural food } \\
\text { supplements } \\
\text { are effective in } \\
\text { preventing the } \\
\text { disease }\end{array}$} & \multirow{2}{*}{ Yes } & 27 & 28 & \multirow{8}{*}{0.151} \\
\hline & & $52.9 \%$ & $70 \%$ & \\
\hline & \multirow{2}{*}{ No } & 8 & 1 & \\
\hline & & $15.7 \%$ & $2.5 \%$ & \\
\hline & \multirow{2}{*}{ Not sure } & 6 & 5 & \\
\hline & & $11.8 \%$ & $12.5 \%$ & \\
\hline & \multirow{2}{*}{ Don't know } & 10 & 6 & \\
\hline & & $19.6 \%$ & $15 \%$ & \\
\hline \multirow{8}{*}{$\begin{array}{l}\text { Do you believe } \\
\text { that dietary } \\
\text { supplements } \\
\text { are effective in } \\
\text { preventing the } \\
\text { disease }\end{array}$} & \multirow{2}{*}{ Yes } & 35 & 25 & \\
\hline & & $68.6 \%$ & $62.5 \%$ & \\
\hline & \multirow{2}{*}{ No } & 2 & 6 & \\
\hline & & $3.9 \%$ & $15 \%$ & \\
\hline & \multirow{2}{*}{ Not sure } & 6 & 4 & \\
\hline & & $11.8 \%$ & $10 \%$ & \\
\hline & \multirow[b]{2}{*}{ Don't know } & 8 & 5 & \\
\hline & & $15.7 \%$ & $12.5 \%$ & 0.323 \\
\hline
\end{tabular}

Table 7: Association between stages and dietary supplements.

Results of table 8 reveal that there was a significant statistical association between stages and source of knowledge about the disease most (56.7\%) of first year students and three quarters (75\%) of second stage said that their source of knowledge about the disease was social media, (29.4\%) of first stage and only $(2.5 \%)$ of second stage got knowledge about the disease from TV, a small amount only (2\%) of first year students and $(2.5 \%)$ of second stage had knowledge about the disease from journals, and finally $(11.8 \%)$ of first stage and (20\%) of second stage did not follow the updates. Chi square test was significant, and p-value was (0.003). 
COVID-19 Dental Students' Knowledge of Medical Technical Institute Dental Assistant Department (Erbil-Iraq) A Comparative Study

\begin{tabular}{|c|c|c|c|c|}
\hline \multirow{2}{*}{ Variable } & \multirow{2}{*}{ Categories } & \multicolumn{2}{|c|}{ Stage } & \multirow{2}{*}{ P-value } \\
\hline & & First & Second & \\
\hline \multirow{4}{*}{$\begin{array}{l}\text { Sources of } \\
\text { knowledge } \\
\text { about the } \\
\text { disease }\end{array}$} & Social media & $29(56.9 \%)$ & $30(75 \%)$ & \multirow{4}{*}{0.003} \\
\hline & $\mathrm{TV}$ & $15(29.4 \%)$ & $1(2.5 \%)$ & \\
\hline & Journals & $1(2 \%)$ & $1(2.5 \%)$ & \\
\hline & $\begin{array}{c}\text { don't follow the } \\
\text { updates }\end{array}$ & $6(11.8 \%)$ & $8(20 \%)$ & \\
\hline
\end{tabular}

Table 8: Association between stages and source of knowledge.

\section{Discussion}

To the best of our knowledge, this is the first representative survey that provides comparative insight on the knowledge and perception of dental assistant students on COVID-19 in Erbil, Iraq. This study has several limitations, one of them that it was conducted exclusively in one institution, hence our results cannot be generalized into another setting or medical institution, furthermore, measuring outcomes through virus-related information is relatively updated is another limitation as many protection measures are still under global investigation. No similar study is currently available to compare these findings with due to the limited number of publications on this topic. The current study assessed dental knowledge about COVID-19, its symptoms transmission pathway, control and preventive measures, this knowledge is critical in students' future practices and attitudes towards COVID-19 patients. COVID-19 challenged dental schools worldwide and the higher education has not been immune to it $[24,25]$.

Regarding gender, females' responses were more predominant than males regarding preventive behaviors, this might be due to the greater female sample size $(75.82 \%)$ compared to the male (24.18\%), also females have favorable attitudes and knowledge toward COVID-19, this result is in accordance with other studies conducted in China and Malaysia [26,27], in contrast to other studies conducted in Egypt and Bangladesh which found no gender differences [28,29] (Figure 1).

Concerning the cause of COVID-19, vast majority of first and second stages $(96.1,92.5 \%)$ thought that the cause of COVID-19 was a virus with non-significant difference between them, this knowledge level was high in comparison to the Jordanian, Palestinian and Indonesian students $(77.1,68.1,60 \%)$ respectively [30-32].

So dental schools must deal with the dilemma of students $[33,34]$, while (4-8\%) of both stages struggled in recognizing the cause of the pandemic we are facing since 2019 until now which is a worrisome problem.

This misunderstanding shed light on the necessity of schools to prepare their educational materials in order to provide the students with reliable information [34], videos, summaries and skills designed to support the learning of health care students.

Droplets spread and fomites are the main modes of transmission by respiratory system in intrapersonal contacts especially during sneezing, dry coughing or even talking [35], the virus is present, but transmission through this route has not conclusively confirmed [36]. It can occur with droplets ejected during speaking, coughing, and sneezing. Droplets and aerosols (both kind of particles) comes out of the patient should be considered hazardous [37-39].

COVID-19 in dentistry may be transmitted through air, droplets, and contacts during clinical procedure. Not only the professionals could act as transmitters, but they could also become infected during human-to- human transmission or by contact with contaminated instruments or surfaces $[40,41]$. Transmission can occur with droplets ejected during speaking, coughing or sneezing and through aerosols.

Routes of transmission - as in table 1 - in this study revealed statistical significant difference between stages and routes of transmission for $1^{\text {st }}$ and $2^{\text {nd }}$ stages respectively $(84.3,55 \%)$ at P 0.007 level, participants thought direct contact with infected droplets is the most popular route of transmission, this result is in accordance with a multi-country online survey that showed (92\%) of respondents know that COVID-19 could be transmitted through breathing infected droplets and direct contact with aerosols [42,43] and it's less than that of Saudi Arabia study which revealed that majority of participants $(92 \%)$ believed that mode of transmission was droplet infection followed by direct fluid transmission (54.1\%) and direct skin-to-skin contact (30.8\%) [44] and it's greater than another study conducted also in Saudi Arabia among 412 respondents from King Saud University, findings indicated that majority of participants (69.66\%) showed low level of awareness related to the mode of transmission of disease [45]. Also, our result was greater than a study conducted in Iran where about half of respondents among 778 total sample answered incorrectly about the transmission medium i.e., air, many respondents selected ore-fecal routes or other less relevant ones, so our students' knowledge level, according to the statistics, is more advanced [46]. 
Concerning interaction with animals: our study showed statistically significant difference between $1^{\text {st }}$ and $2^{\text {nd }}$ stages $(62.7,35 \%)$ respectively at $\mathrm{P} 0.017$, they replied yes, the virus could be transmitted through interaction with animals, but this percentage was lower than that of Italian students where almost all the respondents $(97.2 \%)$ reported that the source of SARS-COV-2 are bats [47].

Concerning symptoms duration range (Table 2): the estimated incubation period of COVID-19 is up to 14 days [10,48] so it's in accordance with our study which revealed that symptoms appear with (7-14) days percentage was $(64.7,65 \%)$ for $1^{\text {st }}$ and $2^{\text {nd }}$ stages respectively with non-significant difference, while symptoms duration range (14 days) was $(45.1,57.5 \%)$ for $1^{\text {st }}$ and $2^{\text {nd }}$ stages respectively with non- significant difference. But this percentage was lower than a study conducted in Italy of the essential knowledge about COVID-19 in potentially exposed person, SARS-COV-2 has an estimated incubation period of 2-14 days (at 5 - 14 days average) [47].

Concerning if signs and symptoms increase with increasing severity most participants percentages for both stages (74.5\%, 70\%) was with non-significant difference they replied yes that it does increase with increasing severity, they mostly perceived COVID-19 as a severe disease, classified the risk of infection as high and considered the pandemics to have strongly impacted to dental school. In this sense, we can discuss that teaching and learning have been profoundly affected $[11,17]$.

Concerning how can students differentiate COVID-19 virus from common cold and flu virus, more than half of the total sample of both stages replied yes, they could differentiate it from common cold and flu virus $(52.9,52.5 \%)$ respectively. This finding contrasted with that of Saudi Arabian students, where simple aspects to differentiate between symptoms of common cold, flu and COVID-19 virus was not reported correctly by majority of the study participants [49].

Concerning risk factor groups as it is shown in table 3 , majority of the answers were "all of the above," (47.1,65\%) for both stages respectively with non-significant difference, those groups are more critical to the potential risk of infection by going outside [50].

Higher level of oral hygiene could decrease the need for a person to attend dental clinic except emergency matters and could significantly help the person to remove the virus from the body at early contamination phase in day-to-day life [51]. To reduce the bacterial load in the mouth and the risk of bacterial superinfection especially in patients who are prone to altered biofilms due to diabetes, hypertension and cardiovascular diseases [52], so this percentage is regarded an acceptable knowledge level. In general, older age and the existence of underlying comorbidities (e.g., diabetes, hypertension and cardiovascular diseases) were associated with poor prognosis $[26,53,54]$.

Concerning protective measures, there has been no evidence from randomized controlled trials to recommend any specific anticovid treatment, so the management of COVID-19 has been largely supportive [55]. Currently, the approach to COVID-19 is to control the source of infection, use infection prevention and control measures to lower the risk of transmission and provide early diagnosis, isolation and supportive care for affected patients e.g., lopinavir, remedesivir [53].

Also using appropriate protective wearing is critical, given the fact that the saliva and dental fluids spreading have the potential of virus transmission because of the close distance between patients and professionals [12,56], this is in accordance with our findings for both stages $(90.2,82.5 \%)$ respectively with non-significant difference as in table 4 .

Concerning hand sanitizing majority of participants for both stages $(56.9,55 \%)$ respectively revealed that hand sanitizing is an effective measure to prevent and minimize transmission of COVID-19 with non- significant difference, this figure is regarded excellent compared to Saudi Arabian study [57] where only 25\% of dental assistants recommended hand soap cleaning time for 40 seconds, this clearly emphasizes the significance of the adequacy of viral prevention knowledge across professionals and assistants during pandemics periods, these results show improvement in knowledge compared with a previous study also conducted in Saudi Arabia (48.3\%) [43]. Our result was acceptable with that of Jordanian students [30,31] and Indian students [58] they agreed on the importance of hand sanitizing. But these results were lower than that of Palestinian and Turkish study [31,59].

Concerning use of alcoholic wipe tissues, our study revealed non-significant difference between both stages (45.1, 47.5\%) respectively, they replied (yes) that the use of alcoholic wipe tissues is effective against COVID-19, this percent was lower than the Turkish study (84.9\%) [59].

Concerning mask types regarding their effectiveness in preventing disease or not, majority of participants replied yes, medical 
type is effective in preventing disease $(72.5,65 \%)$ for both stages with non-significant difference, also if the type of mask affects preventive measures or not, their reply was (yes), medical is effective in preventing disease for both stages $(54.9,52.5 \%)$ with non-significant difference respectively. To prevent cross infection, standard measures should be taken such as disposable medical mask [40]. This percentage is higher than the Turkish study (44.41\%) of respondents received a mask response as individual measures taken by them [59] and our percentage was approximately the same with the Saudi Arabian study where (76.83\%) participants had a negative attitude toward safety precautions i.e., (mask should be worn most of the time to prevent the infection from escalating) and $(82.25 \%)$ of participants reflected a positive attitude towards the use of a mask especially of the carriers with a droplet spread disease [45], also in Palestinian study, students selected wearing masks is an important measure [31], also in Chinese studies a significant positive association was determined between increasing knowledge and effective preventive measures practices linked with marked increase willingness of participants to wear a mask and reluctance in going to a crowded place [27], in a Pakistani study in Karachi, majority of students considered the proper use of face masks was the common opinion stated by the participant to overcome the pandemic [60].

Concerning mask types (medical, non-medical), before the pandemic, N95 masks and similar respirators were uncommon in dentistry [61], their use requires fit testing to ensure proper seal around the nose and the mouth, our percentage was greater (72.5, $65 \%$ ) that Eastern, Mediterranean, Europe, North America and Western Pacific countries (63.2\%, 41.6\%, 67.8\%, 40.5\%) respectively [62], so our students complied higher knowledge level.

Mask N95 should be used in addition to standard measures for the person who has infection suppression or infected, when it comes to infection control in the field of health, N95 masks with particle filters are preferred. These include 3 layers, being hypoallergenic, forming a liquid barrier, being tear resistant, and providing 99\% bacteria and $95 \%$ particle filtration [63].

Our result was in contrast with Duruk., et al. study [64] that evaluated attitudes and behaviors of Turkish dentists towards COVID-19 pandemic, although they were conscious of the virus' transmission, they did not use N95 masks.

As SARS-COV-2 shedding occurs in various stages of the disease, including pre-symptomatic phase andin patients who are asymptomatic [65], the ADA'S Interim Mask and Face shield guidance requ- ires the use of the highest-level respirators when dealing with all patients with the assumption that they all can transmit the disease $[66,67]$.

Concerning how many hours does the virus stay on solid surfaces as it is shown in table 5 , there was significant difference between both stages $(27.5,32.5 \%)$, this result is in accordance with WHO which stated that SARS-COV-2 can persist on surfaces for a few hours or up to several days, depending on the type of surface [68]. As a result, both kind of particles or anything that comes out of the patient should be considered hazardous, COVID-19 virus adheres and persists on these surfaces for several days, so it could present a risk of transmission if these surfaces are not properly decontaminated $[30,69]$.

Concerning if it's safe to work in dental clinic during COVID-19 pandemic or not, the reply of students was it's not safe to work in dental clinic for both stages with non-significant difference for both stages $(47.1 \%, 45 \%)$ respectively at P0.483, this percentage was lower than the Palestinian study where (82\%) of students preferred to avoid working with suspected COVID-19 patients and (58\%) refused to treat patients who showed URT (upper respiratory tract infection) [31].

Table 6 do treatment options of COVID-19 vary according to case severity, majority of students $(70.6 \%, 57.5 \%)$ for both stages thought that treatment options of COVID-19 vary according to case severity with non-significant difference, they mostly perceived COVID-19 as a severe disease classified with the risk of infection as high.

In this sense, we can discuss that teaching and learning have been profoundly affected $[11,17,70]$.

Concerning that if the vaccine is effective in preventing the disease, a good percentage of both stages $(45.1,45 \%)$ respectively replied (yes), the vaccine is effective in combating virus, this percentage was higher than Malaysian students where (78.2\%) selected (false) for getting vaccination [27], also this percentage was higher than a study conducted in Australia on general population and vaccine intentions of COVID-19, one third of participants (33\%) were worried about it and are taking precautionary steps [71].

Table 7 revealed that if natural food supplements are effective in preventing the disease, the highest percentage of both stages who replied (yes) regarding its effectiveness were $(52.9,70 \%)$ in preventing the disease with non-significant difference. The label 
of the natural food supplement may claim certain health benefits, anti-viral activities like onion, garlic, and ginger but, unlike medicines, these supplements cannot claim to cure, treat or prevent the disease [72-75].

Concerning if the dietary supplements are effective in preventing the disease or not, a high percentage of both stages replied (yes) it's effective $(68.6,62.5 \%)$ with non-significant difference between them. Unlike drugs, supplements aren't permitted to be marketed for the purpose of treating, diagnosing, preventing, or curing diseases. But there is evidence from laboratory experiments and clinical data demonstrating a preventive role for vitamin $\mathrm{D}$ against viral RTIS (respiratory tract infection system), particularly in those suffering from very low plasma concentration of vitamin D which is important for treatment of COVID-19 cases [76].

Table 8 concerning source of knowledge, there was a significant association between stages and source of knowledge about COVID-19, social media (56.9, 75\%), TV $(29.4,2.5 \%)$, journals $(2$, $2.5 \%)$, while for those who don't follow the updates it was (11.8, $20 \%$ ) respectively. Regarding source of dental knowledge, the highest percentage of both stages who used social media as a source of information about COVID-19 this result is in line with Jordanian studies $(77.1,83.4 \%)$ used social media as the primary source of information $[30,34]$, this indicates the significant influence of social media as a source of information using these channels effectively by institutional and major organization to convey their main awareness messages about the disease. The most positive dental knowledge concerning the virus among both stages was the cause of COVID-19 virus, preventive measures, routes of transmission, signs increase with increasing severity, mask types, treatment vary according to severity, dietary supplement, symptoms appear within 7-14 days, interaction with animals, hand sanitizers and source of knowledge.

As a comparison between the two stages: $1^{\text {st }}$ stage was better than $2^{\text {nd }}$ stage in the knowledge of routes of transmission, interaction with animals, preventive measures and source of dental knowledge (which was mostly taken from social media) with significant difference, also in mask types, if treatment varies according to severity, hand sanitizers and if it's safe to work in dental clinic and signs increase with increasing severity (yes) but with non-significant difference.

$2^{\text {nd }}$ stage was better than $1^{\text {st }}$ stage in the knowledge of how many hours does the virus stay on solid surfaces, interaction with ani- mals, and source of dental knowledge (social media, journals, don't follow updates) with significant difference but, symptoms duration range (14 days), people at risk, natural food supplement with nonsignificant difference.

The first stage was equivalent to the second stage in terms of knowledge of virus causes, symptoms; COVID-19 signs differing from cold and flu virus, hand sanitizer, use of alcoholic tissue, vaccine efficiency, and dietary supplement. The notion that the $1^{\text {st }}$ stage students' knowledge level was more extensive than the $2^{\text {nd }}$ stage can be ascribed to the fact that their number was more prominent than the $2^{\text {nd }}$ stage and their application to (TV) as a source of knowledge was significantly more significant than the $2^{\text {nd }}$ stage.

The second stage was better than the $1^{\text {st }}$ stage in other aspects; their curriculum devotes a considerable portion of its course infection control preventive practices to learn more about this novel disease than the $1^{\text {st }}$ stage. Participants' knowledge of both stages was found to be lacking in some areas, so prevention and guidelines for the COVID-19 virus should be included in the first stage curriculum to improve and broaden their knowledge and understanding of this disease. Furthermore, students in the Medical Dental Assistant Department should be aware of COVID-19 prevention measures. As previously stated, part of their curriculum includes learning and practicing infection against the most virulent viral diseases such as HIV, Aids, viral hepatitis, and the fatal one, COVID-19, so they must be aware of that.

\section{Conclusion}

Although dental students demonstrate an acceptable general knowledge about COVID-19, some aspects of the disease and control measures need to be better addressed by dental schools to ensure a safer return to presential activities. Moreover, as dental students did not present good perceptions about COVID-19 in the dental practice, these findings could be better attributed to the novelty of this disease, their concerns need to be consulted and considered with published reports on human-to-human transmission in the community and transmission through aerosols is highly possible. Further studies are required to assess the knowledge and practice of the students after holding training courses.

\section{Recommendations}

There are practical guidelines recommended for dentists and dental staff by the center for disease control and prevention (CDC), the American Dental Association (ADA) and the World Health Organization (WHO) to control the spread of the disease $[34,77,78]$. 
Some guidelines and reports have provided useful information about signs and symptoms of the disease, ways of transmission, and referral mechanisms to increase dentists' knowledge and prevention practices, so they could contribute at a population level in disease control and prevention [32,34]. So, these guidelines can be included in the curriculum of dental schools' and universities.

\section{Suggestions}

Thus, as a final remark, we suggest that our questionnaire might be a useful tool and could be applied by dental schools.

\section{Appendix}

Questionnaire form

- Causes of COVID-19: A. Bacteria. B. Viruses. C. Parasite. D. Others. E. I don't know.

- Routes of transmission:A. Direct contact. B. Sneezing. C. Contaminated food or drink. D. Focally. E. I don't know.

- Does the interaction with animals expose people to the virus: A. Yes. B. No. C. It depends on the type of animal,

- D. I don't know.

- Symptoms appear within: A. 2-5 days. B. 5-7 days. C. 7-14 days. D. Amonth.

- Symptoms duration range: A. Last for 5 days. B. 14 days. C. A month. D. I don't know.

- People at risk are: A. Diabetic. B. Hypertensive. C. Obese. D. CA patients. E.All of the above. F. I don't know.

- Preventive measures of wearing masks and gloves are A. Beneficial. B. Not necessary. C. Doesn't prevent disease. D. I don't know.

- Using hand sanitizer: A. Effective. B. Not necessary. C. Depends on the type of sanitizer. D. I don't know.

- Is the use of alcoholic wipe tissues more effective than sanitizers: A.Yes. B. No. C. Not really. D. I don't know.

- Which of the following mask types (medical-non medical) are more effective in preventing the disease: A. Medical. B. Non-medical. C. Both. D. I don't know.

- Does the type of mask affect preventive measures: A. Yes, because N95 is FDA approved. B. No, because non- medical masks are efficient. C. Not sure, because I don't know the types of masks. D. I don't wear a mask.

- Do signs and symptoms' number increase with increasing severity of the disease: A. Yes. B. No. C. Not sure. D. I don't know.
- Can COVID-19 virus be differentiated from common cold and flu, air pollution (allergy): A. Yes. B. No. C. Not sure. D. I don't know.

- How many hours does the virus stay on solid objects/surface areas: A. 8 hours. B. 2 days. C. 23 days. D. Not very specific.

- Do treatment options of COVID-19 vary according to case severity: A. Yes.

B. No. C. Not sure. D. I don't know.

- Do you believe that natural food supplements like onion, garlic, spice sumac \& black seed are effective in preventing the disease: A. Yes. B. No. C. Not sure. D. I don't know.

- Do you think that dietary supplements like vitamin C, vitamin $D$, zinc and selenium are effective in preventing the disease: A. Yes. B. No. C. Not sure. D. I don't know.

- Is it safe to work in dental clinic during COVID-19 pandemic: A. Yes. B. No. C. Not sure. D. I don't know.

- Do you think that vaccine is effective in preventing the disease: A. Yes. B. No. C. Not sure. D. I don't know.

- What are the sources of your knowledge about the disease: A. Social media. B. TV.C. Journals. D. Idon't follow the updates.

\section{Bibliography}

1. Triggle CR., et al. "Covid-19: learning from lessons to guide treatment and prevention interventions". Msphere 5.3 (2020).

2. World Health Organization (WHO) coronavirus (covid-19): Events as they happen (2020).

3. Singhal T. "A review of coronavirus disease-2019 (covid-19)". Indian Journal of Pediatrics 87 (2020): 281-286.

4. World meters. "Coronavirus update (live) world meters" (2020): 1-22.

5. U.S. Department of labor. "Guidance on preparing workplaces for covid-19" (2020).

6. Mohebati A., et al. "Current risks of (Larch mt)". 11 (2020): 325-331.

7. Zemouri C., et al. "A scoping review on bio-aerosols in health care and the dental treatment environment". PLOS One 12 (2017): e0178007.

8. Chais S. "Are dental schools adequately preparing dental students to face outbreaks of infectious diseases such as covid-19?". Journal of Dental Education 84 (2020): 631-633. 
9. Adams JG and walls RM. "Supporting the health care workforce during the covid-19 global epidemic". Journal of the American Medical Association 323.15 (2020): 1439-1440.

10. Li Q., et al. "Early transmission dynamics in Wuhan, China of novel coronavirus_infected pneumonia". The New England Journal of Medicine 382.13 (2020): 1199-1207.

11. Practic C., et al. "Covid-19: its impact on dental schools in Italy, clinical problems in endodontic therapy and general considerations". International Endodontic Journal 53.5 (2020): 723725.

12. Meng L., et al. "Coronavirus Disease 2019 (covid-19) Emerging future challenges for Dental and oral Medicine". Journal of Dental Research 99.5 (2020): 481-487.

13. Desai BK. "Clinical implications of the covid-19 pandemic on dental education". Journal of Dental Education 84.5 (2020): 512.

14. Iyer P., et al. "Impact of covid-19 on dental education in the United States”. Journal of Dental Education 84.6 (2020): 718722.

15. Liu X., et al. "Impact of covid-19 epidemic on live online dental continuing education". European Journal of Dental Education (2020): 1-4.

16. Machado RA., et al. "Covid-19 pandemic and the impaction on dental education: discussing current and future perspectives". Brazilian Oral Research 34 (2020): e083.

17. Wu DT., et al. "The impact of covid-19 on dental education in North America-where do we go next?" European Journal of Dental Education (2020): 1-3.

18. Samer Nazzal. "Covid-19 in Palestine".

19. Stewardson D., et al. "Occupational exposures occurring in students in a UK dental school. I". European Journal of Dental Education 6 (2002): 104-113.

20. Kennedy J and Hasler J. "Exposures to blood and body fluids among dental school based dental health care workers". Journal of Dental Education 63 (1999): 464-469.

21. WHO clinical management of covid-19 (2020).

22. Covid-19: Manuel de Boas praticas em Biosseguran ca para Ambientes odontologicos e lancado com apoio institutional do
CFO-CFO (2020).

23. Rosales-Mendoza S., et al. "Challenges and opportunities for the biotechnology research community during the corona virus pandemic". Trends in Biotechnology 38 (2020): 823-824.

24. Sahu P. "Closure of universities due to coronavirus disease 2019 (covid-19): Impact on Education and Mental Health of students and academic stuff". Cureus 4 (2020): 4-9.

25. "School closures caused by coronavirus (covid-19)" (2020).

26. Kui L., et al. "Clinical characteristics of novel coronavirus cases in tertiary hospitals in Hubi Province". Chinese Medical Journal (Engl) 133.9 (2020): 1025-1031.

27. Eu Green., et al. "COVID-19 knowledge, attitude and preventive behaviors of medical and dental students". International Journal of Medical and Biomedical Studies 5.3 (2020): 236256.

28. Abdelhafiz AS., et al. "Knowledge perception and attitude of Egyptians toward the novel coronavirus disease (covid-19)" (2020).

29. Wadood MA., et al. "Knowledge, attitude, practice and perception regarding covid-19 among students in Bangladesh survey in Rajshah University". medRxIv (2020).

30. Olaimat AN., et al. "Knowledge and information sources about covid-19 among university students in Jordan: across-sectional study". Frontiers in Public Health 29 (2020): e 254.

31. Ruwaa., et al. "Knowledge and attitudes among dental students about covid-19 and its precautionary measures: acrosssectional study". 27.1 (2020).

32. Ar Melia., et al. "Covid-19 awareness among dental professionals in Indonesia". 7 (2020): 5897590

33. Mohabati A., et al. "Current risks of occupational blood-borne viral infection". Surgery Infection (larchmt) 11 (2010): 325331.

34. Jamal M., et al. "Overview of transition recommendations for covid-19 transmission control in dental care setting". Oral Disease (2020).

35. Laure SA., et al. "The incubation period of coronavirus disease 2019 (covid-19) from publicly reported confirmed cases: estimation". Annals of Internal Medicine 172.9 (2020): 577-582. 
36. Tokk-W., et al. "Consistent detection of 2019 novel coronavirus in saliva”. Clinical Infectious Disease 71.15 (2020): 841-843.

37. Wang S., et al. "Bioinspired surfaces with superwett ability: new insight on theory, design, and applications". Chemical Reviews 115.16 (2015): 823-893.

38. Khalid-Abad MS., et al. "Super hydrophobic antibact. Cotton textiles". Journal of Colloid and Interface Science 351.1 (2010): 293-298.

39. Khan Mohammadi Chenab K., et al. "Super hydrophobicity: advanced biological and biomedical applications". Biomaterials Science 7.8 (2019): 3110-3137.

40. Peng X., et al. "Transmission routes of 2019-ncov and controls in dental practice". International Journal of Oral Science 12.1 (2020): 1-6.

41. Kamp F G., et al. "Persistence of coronaviruses on inanimate surfaces and its in activation with biocidal agents". Journal of Hospital Infection 104.3 (2020): 246-251.

42. Ammar., et al. "Knowledge of dental academics about the covid-19 pandemics; A multi-country online survey". BMC Medical Education 20 (2020): 399.

43. Cascella M., et al. "Features, evaluation and treatment coronavirus (covid-19) in stat pearls". Treasure Island (FL) (2020).

44. Sulaiman Y Sh., et al. "Knowledge and attitude of dentists, dental auxiliaries, and students regarding the covid-19 pandemic in Saudi Arabia: A cross-sectional survey". BMC Oral Health (2020).

45. AlJasser R., et al. "Awareness toward covid-19 precautions among different levels of dental students in King Saud University, Riyadh, Saudi Arabia" (2020).

46. Farzin S., et al. "Knowledge of Iranian Dentist, Dental Specialists, and Dental students toward covid-19: A preliminary survey of 778 subject". Shiraz E Medical Journal 21.12 (2020): e106515.

47. Francesco B., et al. "Are dental students aware of and knowledgeable about covid-19? A questionnaire-based investigation". The Open Dentistry Journal 14 (2020).

48. Backer JA., et al. "Incubation period of 2019 novel coronavirus (2019-ncov) infection among travellers from Wuhan, China, 20-28 January 2020". Euro Surveillance 25.5 (2020).
49. Mir FA Quadri., et al. "Novel coronavirus disease (covid-19) awareness among the dental interns, dental auxiliaries and dental specialists in Saudi Arabia: A nationwide survey study". Journal of Infection and Public Health 13 (2020) 856-864.

50. Guo H., et al. "The impact of covid-19 epidemic on the utilization of emergency dental services". Journal of Dental Sciences 15.4 (2020).

51. Lucaciu O., et al. "Oral health care during the covid-19 pandemic". Journal of Dental Sciences (2020).

52. Sampson VJBDJ. Oral Hygiene Risk Factors 228.8 (2020): 569.

53. Wang D., et al. "Clinical characteristics of 138 hospitalized patients with 2019 novel coronavirus-infected pneumonia in Wuhan, China". JAMA 323.11 (2020): 1061-1069.

54. Yang Y., et al. "Epidemiological and clinical features of the covid 19 novel corona virus outbreak in China". MedRXiv (2020).

55. World Health Organization 2020 a: clinical management of severe acute respiratory infection when novel coronavirus (2019-ncov) infection is suspected: interim guidance" (2020).

56. Sabino-Silva R., et al. "Coronavirus covid-19 impacts to dentistry and potential salivary diagnosis". Clinical Oral Investigations (2020): 1-3.

57. Gaffar BO., et al. "Knowledge and practices of dentists regarding MERS-Cov. Across-sectional surveying in Saudi Arabia". Saudi Medical Journal 40 (2019): 714-720.

58. Das D., et al. "Awareness among undergraduate students of Mangalore city regarding novel coronavirus (covid-19)- A questionnaire study". Disaster Medicine and Public Health Preparedness 17 (2020): 1-9.

59. Osman Atas and Tuba Talo Yildrim T. "Evaluation of knowledge, attitudes and clinical education of dental students about covid-19 pandemic". Peer Journal 8 (2020): e9575.

60. Ahmed N., et al. "Concerns of undergraduate medical students towards an outbreak of covid-19".

61. Coulthard P. "Dentistry and coronavirus (covid-19): moral decision-making”. British Dental Journal 228.7 (2020): 503-505.

62. Lara G., et al. "Dentists' knowledge, attitudes and professional behavior toward covid-19 pandemic". JADA 152.1 (2021). 
63. Ahmad IA. "Rubber dam usage for endodontic treatment: a review". International Endodontic Journal 42 (2009): 963-972.

64. Duruk G., et al. "Investigation of Turkish dentists, clinical attitudes and behaviors toward the covid-19 pandemic: a survey study". Brazilian Oral Research 34 (2020): 054.

65. Kim ES., et al. "Clinical course and outcomes of patients of patients with severe acute respiratory syndrome coronavirus 2 infections: A preliminary report of the first 28 patients from the Korean cohort study on covid-19". Journal of Korean Medical Science 35.13 (2020): e142.

66. American Dental Association. "Interim mask and face shield guidance" (2020).

67. Centers for disease control and prevention. Interim clinical guidance for management of patients with confirmed corona virus disease (covid-19) CDC stacks (2020).

68. World Health Organization. "Questions and Answers on coronavirus" (2020).

69. Negahdari pour M. "The battle against covid-19: where do we stand now?" Iranian Journal of Medical Sciences 45.2 (2020): 81.

70. Van Doren EJ., et al. "Students' perceptions on dental education in the wake of covid-19 pandemic". Journal of Dental Education (2020): 3-5.

71. Faasse K., et al. "Public perceptions of covid-19 in Australia: perceived risk, knowledge, health protective behaviors, and vaccine intentions". Frontiers in Psychology (2020).

72. https://www.fda.gov/food/buy-store-safe-food

73. Ahasan Ullah Khan., et al. "Effect of coronavirus disease (covid-19) on Agricultural sectors in Bangladesh: a review". International Journal for Asian Contemporary Research 1.2 (2021): 89-97.

74. Ahasan Ulla Khan., et al. "Novel Coronavirus Disease (covid-19): pandemic situation in Bangladesh". NUJS Journal of Regulatory Studies 2.5 (2020).

75. Ahasan Ullah Khan., et al. "A review on coronavirus disease (covid-19) epidemic threat for global health in 2020". American Journal of Microbiological Research 8.2 (2020): 57-62.
76. https://newsinhealth.nih.gov/2013/08/should-you-takedietarysupplements

77. Ghais. "Are Dental schools adequately preparing dental students to face the outbreaks of infectious diseases such as covid-19?". Journal of Dental Education 84.6 (2020): 631-633.

78. Desai BK. "Clinical implications of the covid-19 pandemic of dental education". Journal of Dental Education 84.5 (2020): 512.

Volume 5 Issue 11 November 2021

(C) All rights are reserved by Faraed Dawood Salman and Jabbar Hussein Kamel. 